\title{
Economic Value of Urban Green Space: A Travel Cost Approach for Viharamahadevi Urban Park, Sri Lanka
}

\author{
H.M.L.P. Karunarathne ${ }^{1}$ and U.A.D.P. Gunawardena ${ }^{2 *}$ \\ ${ }^{1}$ Department of Estate Management and Valuation, University of Sri Jayewardenepura, \\ Nugegoda, Sri Lanka \\ ${ }^{2}$ Department of Forestry and Environmental Science, University of Sri Jayewardenepura, \\ Nugegoda, Sri Lanka
}

Date Received: 10-05-2020 Date Accepted: 25-06-2020

\begin{abstract}
Urban green spaces could bring cities and their inhabitants with vitality in terms of ecological, social, and economic benefits. Recognising and estimation of economic values of parks is important for their sound management and for justification of the current use over various alternative uses. Non recognition of values of the services of such green spaces may lead to unsound management and degradation resulting in depriving urban communities of those benefits. Viharamahadevi Urban Park is the oldest and largest park in Colombo which offers recreation and green space to the inhabitants and visitors of the city. The purpose of this study is to estimate the recreational value of the Park using Individual Travel Cost Method (ITCM). Visitors of Viharamahadevi Urban Park selected using purposive sampling method were interviewed with a structured questionnaire. Data on visitation frequencies, preferences for park characteristics and socio economic parameters were collected using face-to-face interviews. In order to cater for the data issues of the ITCM, a zero truncated negative binomial regression analysis was performed in estimating the demand function. Results indicate that household income and the enjoyment of the visitors significantly and positively determine the number of visits made by the people. The annual social welfare generated from the recreational value of the Viharamahadevi Park is LKR 55.7 billion. The estimated value will be able to provide significant guidance towards future park management decisions.
\end{abstract}

Keywords: individual travel cost method, Viharamahadevi park, recreation values, urban green space

\section{Introduction}

Urban green spaces could insert cities with vitality in terms of ecological, social, and economic benefits. Research indicate that having urban green spaces may largely mitigate social problems in the urban areas and provide an attractive environment to residents, lessen urban heat island effect, act as carbon sink, increase the access to shade, improve water penetration, protect bio-diversity, and eventually improving well-being of people (Ulrich et al., 1991; Zhou and Rana, 2012; Rakhshandehroo et al., 2017). Further, green spaces increase the economic value of spaces, reduces the social gap in the community and ensures socio-environmental sustainability (Chen and Jim, 2008; Zhou and Rana, 2012). Conserving urban green spaces in the city is therefore an important strategy to maintain sustainability (Social, environmental and economic) and it is a major responsibility of municipalities to play a great role in preserving, improving, and maintaining parks in urban areas.

*Correspondence: prasanth@sjp.ac.lk

Tel: +94 714166159

(C) University of Sri Jayewardenepura 
Accordingly, economic valuation of parks can be considered as a valuable source of information not only for the municipalities but for the society in general for a sound management of parks and to understand the services provided by these parks. Moreover, economic efficiency in resource management requires knowledge of the flow of park benefits and costs. The non-recognition of the value of services of ecosystems/ parksmay result in degrading and unsound management of such resources and finally depriving people the full use of the services of these ecosystems. Hence, it is important to identify the recreational values for the sound management of these parks. In that context, valuation can be used to measure the benefits derived from the park (Mathieu et al., 2003; Alvarez and Larkin, 2008). Accordingly, this study intends to determine the recreational value of Viharamahadevi Urban Park, Colombo, Sri Lanka. However, ascertainment of value is a complex task in the absence of market values. In order to value recreational benefits of public parks, different types of valuation approaches can be employed.

The present study has employed Individual Travel Cost Method (ITCM). Accordingly, individuals' willingness to pay for a visit to a site can be estimated based on the number of trips they make at different travel costs (Twerefou and Ababio, 2012). This method is one of the most appropriate means of determining the recreational value of non-market goods like forests and parks. The unique advantage of TCM compared to other valuation approaches is that, the method is based on actual behaviour. Applications of TCM to value recreational resources is abundant in Sri Lanka for wild life parks (Rathnayake and Gunawardena, 2002; Rathnayake and Gunawardena, 2011) viewing leopards (Wickramarachchi and Gunawardena, 2012), botanical gardens (Jayaratne and Gunawardena, 2004 and Madhuwanthika and Gunawardena, 2017) and for urban recreational sites (Marawila and Thibbotuwawa, 2010). This research enhances the knowledge on environmental valuation in the urban park context. The rest of the paper is organized as follows: the next section provides an overview on benefits and economic values of urban parks which is followed by study methodology, results, discussion, conclusion and policy implications.

\section{Urban Parks and their Values}

Urban green space can be recognised as an integrated area comprising natural, semi-natural, or artificial green lands which supply benefits to different groups of people within the city (Tzoulas et al., 2007; Zhou and Rana, 2012). It can be further defined as "an open space situated within the city limits with a good vegetation cover planted deliberately or inherited from pre-urbanisation vegetation and left by design or by default" (Jim and Chen, 2006). Urban green space consists with urban forest as well as other green areas for example, public parks, edges of roads, sport fields, public or private gardens, and remnant patches of natural vegetation as well as individual street trees (Davies et al., 2008; Wu, 2008; Zhou and Rana, 2012). Some researchers also have used the term "green infrastructure" to consider the urban green space as a coherent planning entity (Ahem, 2007; Zhou and Rana, 2012).

Research shows that the availability of urban green space may largely mitigate social problems in the urban context and provide a beautiful and healthy environment to residents (Ulrich et al., 1991; Zhou and Rana, 2012). Urban green space can bring ecological, social, and economic benefits to people resulting in a better quality of life for people (Smith et al., 2005; Barbosa et al., 2007; Jorgensen et al., 2002; Ulrich et al., 1991; Takano et al., 2002; Jackson, 2003; Givoni, 1991; Heidt and Neef, 2008; Zhou and Rana, 2012; Chen and Jim, 2008). Therefore, it is vital to maintain green spaces in the urban areas.

One of the most important reasons for the vulnerability of urban green space is that the value of green space is not directly expressed in monetary terms. As a result, the planners and policy makers cannot clearly understand the values of different land covers, and the decision-making process cannot be 
effectively facilitated. Although benefits of green space cannot be fully measured in a monetary terms, this valuation process can at least provide more weight to green space when making tradeoffs between the green land cover and others (Luttik, 2000; Zhou and Rana, 2012). In other words, valuation gives clear way to explain the extent to which green space benefits people in monetary terms.

\subsection{Valuation of benefits of urban recreational resources}

Several environmental valuation techniques have been developed to measure the economic value of non-marketed environmental goods such as national parks, geo-forest parks, beach, which include Travel Cost Method (TCM), Hedonic Pricing Method, Contingent Valuation Method, and Choice Modelling approach among others (Matthew et al., 2013).

\subsection{Travel cost method}

TCM is an indirect method used for estimating user benefits from visits to recreational sites. The expenditure incurred in getting to the site would be considered as a "price" paid by the visitor for usage of the site and underlying assumption of the TCM is the costs incurred visiting a site in some way reflect the recreational value of that site (Perman et al., 2003). These variables allow for the estimation of a demand function and the estimation of consumer surplus of recreation sites (Freeman, 2003). Despite various practical and theoretical problems in this method, it remains a popular technique for estimating the benefits from a particular outdoor recreational site (Iamtrakul et al., 2005). TCM is relatively uncontroversial, because it is based on standard economic techniques for measuring value, and it uses information from the visitors to the site. Furthermore, TCM is less expensive than the other methods, and the interpretation of results is relatively easier (Limaei, et al, 2014; Farber et al., 2002).

\section{Methodology}

\subsection{Theoretical background}

The ITCM proposes the optimisation problem (Freeman et al., 2014) described in the equation 1.

$$
\operatorname{Max} U(q, I, z) \text {; subject to: } T C \cdot q+z=I \text { and } t *=t_{w}+t_{q}
$$

where: U represents utility obtained from consuming a quantity of a recreational good q; I is income; $\mathrm{z}$ represents the consumption of other goods; and TC are the travel costs. $\mathrm{t}^{*}$ is the discretionary time, $t_{w}$ and $t_{q}$ are the time devoted to work and to travel to the recreational site, respectively; and $w$ represents wage. From the First Order Conditions and assuming rational consumer behavior, the following equation 2 is obtained.

$$
q=f(T C, I, z)
$$

This denotes the recreational demand function of the site, which is determined by travel cost, consumption of other goods and available income. Thus, consumer surplus (CS) per person is given by integration of the demand function. The ITCM proposes a function where the frequency of visits approximates the quantity demanded.

For a given visitor, the demand of visits to a site follows the equation 3.

$$
V_{i}=f\left(T C_{i}, X_{i}\right)+e_{i}
$$

where: $\mathrm{V}_{\mathrm{i}}$ represents the number of visits made by the user to a site during a given period of time; $\mathrm{TC}_{\mathrm{i}}$ is the total cost of travel to the site; $\mathrm{X}_{\mathrm{i}}$ is a vector of additional features including user characteristics such as income, age, or gender, indicators of environmental quality and substitute sites; and ei is an error term (Freeman et al., 2014). 
In the estimation of the previous function, since the number of visits $\left(\mathrm{V}_{\mathrm{i}}\right)$ cannot take continuous values (only integer values), the use of a regression with ordinary least squares can lead to errors. The solution to this is to use a regression model based on a Poisson distribution. The Poisson distribution assumes that the average number of visits is the same as the variance. However, in practice, this assumption is not met since the data show a greater dispersion. Then the most appropriate alternative is the use of negative binomial distributions which allows the variance of the probability function to differ from the mean (Haab and McConell, 2002).

There are two other issues associated with the ITCM. The first issue is that since the demand for visits is collected through on site surveys and the non-users are not included in the sample, the variable for the annual frequency of visits cannot take zero values. Secondly, the probability of being sampled is affected by the number of visits made. Thus, a zero-truncated negative binomial regression is used which reduce the potential bias caused by the presence of truncated variables (Haab and McConell, 2002).

Thus equation 3 can be transformed into the following equation 4.

$$
\log V_{i}=\beta_{0}+\beta_{T C} T C_{i}+\beta_{X} X_{i}
$$

where: $\beta_{\mathrm{TC}}$ is the coefficient for travel cost and $\beta_{\mathrm{X}}$ represents coefficients for other variables

The consumer surplus (for finite travel costs) is given by

$$
C S=q /-\beta_{T C}
$$

where: CS is the Consumer surplus, $\mathrm{q}$ is Average of the total annual number of visits

\subsection{Study site}

Viharamahadevi Park is located in Colombo 07 (Figure 1) with an extent of 18.8 ha (University of Moratuwa, 2011). The park is named after Queen Viharamahadevi, the mother of King Gemunu who was an important figurehead of Sri Lanka's history. This park was developed on the land donated by Charles Henry de Zoysa during the British rule of Sri Lanka and initially named as 'Victoria Park' (CMC, 2020). In 2013, with the commencement of the $23^{\text {rd }}$ Commonwealth Heads of Government meeting in Colombo, the government implemented a complete makeover of the Viharamahadevi park as a beatification project. The fences and gates around the park were removed which restricted free access of visitors and paved pathways, palm trees were added under the project (Lakpura, 2020).

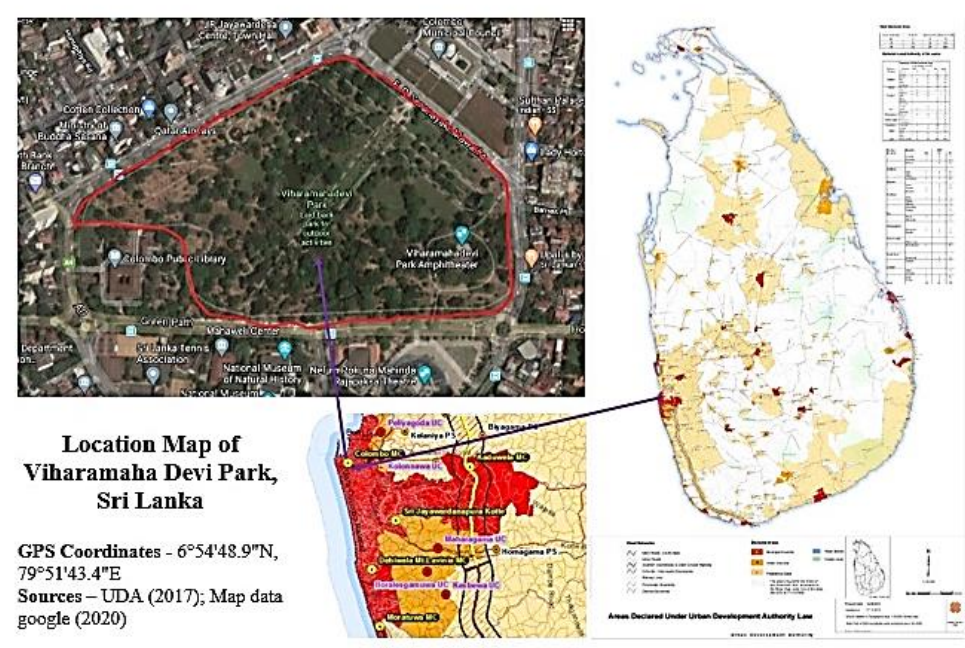




\subsection{Data collection}

Figure 1. Location of Viharamahadevi park.

The primary source of data for the study was a survey conducted among the visitors of Viharamahadevi Urban Park. A detailed questionnaire was developed based on a pilot study conducted in the site. Respondents were asked to report on their origins of travel, travel distances, travel costs (including information on travel modes and travel time), time spent at the site and size of the party. The frequency of travel in a year and the costs spent at the site was also obtained. Preferences for park characteristics were obtained under a likert scale and socio economic parameters such as age, education, employment, household size and income were also collected. Face-to-face style interviews were conducted to confirm that all questions were properly understood. The survey resulted in total usable 100 responses.

\subsection{Estimation of the travel cost function and consumer surplus}

Data were summarised first and then analysed using the Stata statistical package. Total travel cost of individuals was derived using the travel costs (considering the travel mode) and the opportunity cost of time. The Following individual travel cost model (equation 6) was estimated using zero truncated negative binomial regression.

$$
\log V=f(C, E, A, Y, H, N, E d)
$$

where: $\mathrm{V}=$ number of visits made per year by an individual

$\mathrm{C}=$ individual's total cost of visiting site

$\mathrm{E}=$ individual's estimate of the proportion of the day's enjoyment contributed by the visit

$\mathrm{A}=$ age of an individual

$\mathrm{Y}=$ income of individual's household

$\mathrm{H}=$ size of individual's household

$\mathrm{N}=$ size of individual's party

$\mathrm{Ed}=$ level of education of individual

A suitable model with significant variables was selected to establish the demand curve.

\section{Results}

\subsection{Sample Profile}

Table 1 presents the summary statistics related to the sampled respondents. On average the visitation is dominated by relatively young visitors with a mean income of about 50,000 and with a mean travel cost of 1,300. Table 2 presents distribution of gender in the sample, indicating that the visitors are male dominant.

Table 1: Summary Statistics of the survey respondents.

\begin{tabular}{lcccc}
\hline Variable & Mean & Std. Dev. & Minimum & Maximum \\
\hline Age & 38.5 & 9.22 & 17 & 60 \\
Income & 53,500 & $23,170.00$ & 12,500 & 137,500 \\
Number of family members & 4.43 & 1.10 & 2 & 8 \\
Total travel cost & $1,306.3$ & 908.60 & 69 & 5,076 \\
Day enjoyment & 4.08 & 0.49 & 3 & 5 \\
Number of people visited & 4.86 & 4.13 & 1 & 35 \\
Annual visits per year & 6.68 & 8.82 & 1 & 51
\end{tabular}


Table 2. Gender Distribution of the sample.

\begin{tabular}{lcc}
\hline Category & Frequency & Percent $(\%)$ \\
\hline Male & 75 & 75.0 \\
Female & 25 & 25.0 \\
Total & 100 & 100.0 \\
\hline
\end{tabular}

Source: Survey data, 2016

Table 3 summarises education level of the survey respondents. Within the sample, advanced level qualifications represent the highest percentage (70\%) followed by ordinary level qualifications and then by graduates indicating that the park is frequented by educated groups.

Table 3: Education levels of the respondents.

\begin{tabular}{lcc}
\hline Education category & Frequency & Percent $(\%)$ \\
\hline Up to grade 5 & 2 & 2.0 \\
Passed O/L & 28 & 28.0 \\
Passed A/L & 42 & 42.0 \\
Diploma & 5 & 5.0 \\
Graduate & 20 & 20.0 \\
Postgraduate & 2 & 2.0 \\
Professional courses & 1 & 1.0 \\
\hline
\end{tabular}

Table 4: Household income distribution.

\begin{tabular}{lcc}
\hline $\begin{array}{l}\text { Household income } \\
\text { per month }\end{array}$ & Frequency & Percent (\%) \\
\hline$<25,000$ & 1 & 1.0 \\
$25,001-50,000$ & 57 & 57.0 \\
$50,001-750,00$ & 24 & 24.0 \\
$75,001-100,000$ & 15 & 15.0 \\
$100,001-125,000$ & 1 & 1.0 \\
$125,001-150,000$ & 2 & 2.0 \\
Total & 100 & 100.0 \\
\hline
\end{tabular}

Household income distribution (Table 4) indicates that majority of the sample is in the category of Rs. 25,001-50,000. In addition, $81 \%$ of the sample is having household income per month in the range of Rs. 25,000 to 75,000 .

According to Table 05, majority of sample were employed while self-employed and unemployed categories are next in the list.

Table 5: Employment status of the respondents.

\begin{tabular}{lcc}
\hline Job Status & Frequency & Percent $(\%)$ \\
\hline Student & 7 & 7.0 \\
Employed & 52 & 52.0 \\
Self-employed & 20 & 20.0 \\
Unemployed & 17 & 17.0
\end{tabular}


Pensioner $\quad 4 \quad 4.0$

Table 6: Travel modes to arrive at the park.

\begin{tabular}{lcc}
\hline Travel Mode & Frequency & Percent $(\%)$ \\
\hline Bus & 31 & 31.0 \\
Own vehicle & 43 & 43.0 \\
On foot & 1 & 1.0 \\
Bike & 9 & 9.0 \\
Taxi & 1 & 1.0 \\
Trishaw & 13 & 13.0 \\
Other & 2 & 2.0 \\
\hline
\end{tabular}

Table 6 shows that highest percentage of visitors have used their own vehicles. The next highest mode is buses and trishaws and bikes have been used sparingly.

Table 7: Satisfaction about the park.

\begin{tabular}{lccccccc}
\hline & $\begin{array}{c}\text { The } \\
\text { view }\end{array}$ & $\begin{array}{c}\text { The services } \\
\text { provided }\end{array}$ & $\begin{array}{c}\text { Park is } \\
\text { clean }\end{array}$ & $\begin{array}{c}\text { Park } \\
\text { facilities }\end{array}$ & $\begin{array}{c}\text { Easy } \\
\text { accessibility }\end{array}$ & $\begin{array}{c}\text { Relaxing } \\
\text { environment }\end{array}$ & $\begin{array}{c}\text { Enjoyed } \\
\text { being in park }\end{array}$ \\
\hline Mean & 4.78 & 3.28 & 4.77 & 3.47 & 3.51 & 4.55 & 4.52 \\
Median & 5.00 & 3.00 & 5.00 & 3.00 & 3.00 & 5.00 & 5.00 \\
\hline
\end{tabular}

Source: Survey data, 2016

According to the Table 7, visitors are more satisfied with the view, cleanliness, relaxing environment, and enjoyment, respectively where mean values are higher than 4.5 as per the likert scale. In addition, it is evident that people expect more improvement in the context of services, facilities and accessibility.

\subsection{Estimation of the demand function}

A zero truncated negative binomial regression (ZTNBR) was run using Stata statistical software. Several combinations of variables were tested to select the best model. Table 8 gives parameter estimates and full model is given in Table 9.

Table 8: Parameter estimates of ZTNBR.

\begin{tabular}{lc}
\hline Parameter & Value \\
\hline Number of observations & 100 \\
Truncation point & 0 \\
LR chi2 (4) & 18.22 \\
Dispersion & mean \\
Prob>chi2 & 0.0011 \\
Log likelihood & -269.80998 \\
Pseudo R2 & 0.0327 \\
\hline
\end{tabular}

Table 9: Results of the Zero-truncated negative binomial regression.

\begin{tabular}{lcccc}
\hline Variable & Coefficient & Std. Err. & $\mathrm{z}$ & $\mathrm{P}>|\mathrm{z}|$ \\
\hline Income & 0.0000164 & $5.52 \mathrm{e}-06$ & 2.97 & 0.003 \\
Total Cost $\mid$ & -0.0002009 & 0.0001442 & -1.39 & 0.164 \\
Day Enjoyment & 0.6700661 & 0.2432458 & -2.29 & 0.006 \\
Number of people & -0.0761482 & 0.0332672 & -1.95 & 0.022 \\
visited & -1.434487 & 1.084693 & -1.32 & 0.186 \\
Constant & & & & \\
\hline
\end{tabular}




\begin{tabular}{lcc}
\hline Lnalpha & 0.21889 & 0.3207997 \\
alpha & 1.244694 & 0.3992976 \\
\hline
\end{tabular}

LR test of alpha=0: chibar2 $(01)=338.71$ Prob $>=$ chibar $2=0.000$

Zero-truncated negative binomial regression is used to model count data for which the value zero cannot occur and when there is evidence of over dispersion. The model, as a whole, is statistically significant. The value of the coefficient for income suggests that the log count of visits to the park increases by 0.0000164 for each unit increase in income. This coefficient is statistically significant. This finding is in line with the theoretical expectations. The log count of the visits to the park increases by 0.6701 for each unit increase in day enjoyment. This coefficient is statistically significant indicating that people's expectations of the park. It is evident that the log count of visits to the park decreases by 0.0761 for each unit increase in number of people in a group. This coefficient is statistically significant. The total visit cost variable has a negative (-) value which shows that there is an opposite relation between the visit costs and the annual number of visits. In other words, as the visit costs increase, the number of annual visits decreases. Thus, this negative relationship is responsible for the negative slope of the demand curve. These findings are consistent with Kaliampakos and Damigos (1999) and Navrud and Mungatana (1994).

The estimate for alpha is 1.244694. For comparison, a model with an alpha of zero is equivalent to a zero-truncated Poisson model. The likelihood-ratio chi-square test that alpha equals zero is 338.71 with one degree of freedom. This is significant result indicates that the negative binomial model is a better choice than a Poisson model.

Further, the variable of the size of the individual household and size of the individual party, age, and level of education have negative (-) values, which means that increase the size of family, the size of the individual party, age and level of education affect the number of the annual visits negatively. Other variables of household income and day enjoyment had a positive relationship with the number of annual visits.

\subsection{Estimation of consumer surplus}

Next, consumer surplus is calculated to derive the recreational value based on the equation 5 indicated under methodology.

$$
\begin{aligned}
& C S=q /-\beta \\
& C S=6.68 /-(-0.0002009) \\
& C S=6.68 / 0.0002009 \\
& C S=33,250.37
\end{aligned}
$$

As per the above calculation, individual's annual consumer surplus of the Viharamahadevi Park is LKR 33,250.37. Then social welfare or the aggregated consumer surplus for the site is calculated by multiplying the individual consumer surplus with the number of individuals visiting the site annually (Das, 2013). According to the data of Colombo Municipal Council (2016), on average 5,000 individuals visit the park per day. Accordingly, total consumer surplus of the Viharamahadevi Park range from LKR 60,681,925,250 (LKR 60.68 billion) assuming all 365 days with 5000 visitors to LKR 50,706,814,250 assuming 305 days with 5000 visitors (considering 2 months of heavy rainy period). Average CS or the annual social welfare is therefore LKR 55,694,369,750 (55.7 billion).

This value can be compared with the average land value of the park which is LKR $52,640,000,000$ (52.6 billion) assuming an average per perch value of 17.5 million (in 2020 prices). A simple calculation will show that the social welfare can be maximised with the current use of the land. If 
the land were to be sold at its current land value and the money to be invested under the current rates (10\%), this would yield annual financial benefit of LKR 5,264,000,000 (5.2 billion). This value has to be adjusted with the environmental damages done to the site with the development activities associated with such an undertaking. In comparison, current land use which is the park will yield annual welfare of LKR 55.7 billion to the users. In addition, the park provides a greenery for the passersby and the rest of the country including its symbolic value and nonuse values, values which are yet to be realised.

The estimated individual annual consumer surplus (LKR 33,250.37) is comparable with a value of Diyawanna Oya wetlands individual CS value of LKR 36,022.35 and the annual consumer surplus of LKR 3,890 million (Marawila and Thibbotuwawa, 2010). Similar studies related to other urban recreational sites indicate much lower values compared to the present study. For example, Weras Ganga Recreational Park has a value of LKR 138 million (Weerasekara, 2015) and value of Nawala Park of LKR has been estimated as 130 million (Disanayaka, 2015). Compared to above two parks Viharamahadevi Park is located in very significant land lot in the heart of Colombo, and it covers 18.8 ha of land. Further, recent infrastructure development and park beautifications added immense value to the Viharamahadevi Park.

\section{Discussion}

Identification of value of the recreational use of parks is crucial for the sound management and to create the awareness of the services of green spaces for the society in general. The absence of recognising the value of the recreational use of parks may result in degrading and unsound management of these urban parks, making people denied the full use of the services of these green spaces. Further, economically efficient resource management requires knowledge of the flow of park benefits and costs, and in that context, valuation can be used to measure the benefits derived from the park.

Accordingly, this study used ITCM which is based on the assumption that travel costs represent the price of access to a recreational site, and peoples' willingness to pay for visiting a site is thus estimated depending on the number of trips that they make at different travel costs. Accordingly, ITCM measures only the 'use value' of recreation sites, and ITCM is not capable of producing any total economic value. This is because the basis of the technique is the level of use-based costs incurred by visitors in visiting a site. As per the analysis, the social welfare generated from the recreational use value of Viharamahadevi Park is LKR 55,694,369,750. This value is on par with other estimates from ITCM based valuations of urban areas.

Data for the study was obtained through a survey of visitors at the Viharamahadevi Park. Non visitors were not sampled nor their concerns are included in the final estimations. Multiple purpose trips pose complications in the analysis and sometimes the portioning of the cost is not logical. Therefore, this study has only considered only single-purpose trips

The actual total welfare generated by the park is much higher considering many other ecosystem services generated by the park including air purification, carbon storage in the vegetation and provision of bird resting site in the middle of a busy city. There are benefits to the passer by community: a green scenery and for a rest of the country a place with greenery and a land mark in the city of Colombo.

The park can sometimes be congested during school vacations and weekends which may affect the enjoyment obtained by the people. Further research (for example, Rathnayake and Gunawardena, 2013) can be recommended to investigate the effects of such crowding for the benefits obtained by the people. Economic values should not be the only concern in justifying environmental policy decisions 
(Gunawardena, 2012). However, estimates that are inclusive of environmental values (Pearce et al, 1989) are one of the second best choices available at present.

\section{Conclusions and Policy Implications}

Economic values of outdoor recreation could lead to establish better environmental policy decisions. TCM has been mostly used to support such decisions, including investments in recreational infrastructure and recreational management decisions. The estimated annual social welfare value of LKR 55.7 billion for the park implies that the current land use is the best among its many alternative uses. In addition, the park provides a greenery for the passersby and rest of the country derives benefits including its symbolic value and nonuse values, values which are yet to be realised. The unestimated other ecosystem service benefits of the park also provides further economic justification for the park. Additional value enhancements of the park while keeping the nature intact and keeping the visitor crowding effects will increase the benefits obtained by the society. Creating similar parks at least around the boundary of the city will generate immense welfare to the congested city dwellers. The results of this study will provide justifications for such undertakings in many urban city centers in the country.

\section{References}

Ahem, J., 2007. Green infrastructure for cities: the spatial dimension, in Novotny V. and Brown, P. (Eds), Cities of the Future: Towards Integrated Sustainable Water and Landscape (pp. 267-283), IWA Publishing, London.

Alvarez, S. and Larkin, S.L., 2008. Valuing recreational benefits of a national park in Andean Columbia, selected paper prepared for presentation at the southern agricultural economics association annual meetings Dallas.

Barbosa, O., Tratalos, J.A., Armsworth, P.R., Davies, R.G., Fuller, R.A., Johnson, P. and Kevin J.G., 2007. Who benefits from access to green space? A case study from Sheffield, UK, Landscape and Urban Planning, 83:187-195.

Chen, W.Y. and Jim, C.Y., 2008. Assess and valuation of the ecosystem services provided by urban forests, in Carreiro, M.M., Song, Y.C. and Wu, J. (Eds), Ecology, Planning, and Management of Urban Forests: International Perspectives(pp. 53-83), Springer, New York.

CMC, 2020. Retrieved June, 15 from https://www.colombo.mc.gov.lk/parks.php.

Das, S., 2013. Travel Cost Method for Environmental Valuation, Centre of Excellence in Environmental Economics, Madras School of Economics.

Davies, R.G., Barbosa, O., Fuller, R.A., Tratalos, J., Burke, N., Lewis, D., Warren, P.H. and Gaston, K.J., 2008. City-wide relationships between green spaces, urban land use and topography, Urban Ecosystem, 11:269-87.

Disanayaka, D.M.R., 2015. Asses the Social Value of the Nawala Recreational Park-A contingent Valuation Method, Research Report of Department of Estate management and Valuation, University of Sri Jayewardenepura.

Farber, S.C., Costanza, R., and Wilson, M.A., 2002. Economic and ecological concepts for valuing ecosystem services. Ecological Economics, 41:375-392. http://doi.org/10.1016/S09218009(02)00088-5.

Freeman, M., 2003. The Measurement of Environmental and Resource Values: Theory and Methods; Resources for the Future: Washington, DC, USA.

Freeman III, A.M., Herriges, J.A. and Kling, C.L., 2014. The measurement of environmental and resource values: theory and methods. Routledge.

Givoni, B., 1991. Impact of planted areas on urban environmental quality: A review, Atmospheric Environment, 25:289-99. 
Gunawardena, U.A.D.P., 2012. An inquiry into ethical foundations of cost benefit analysis. Journal of Environmental Professionals Sri Lanka, Vol. 1 No. 2

Haab, T., McConell, K., 2002. Valuing Environmental and Natural Resources: The Econometrics of Non-Market Valuation; Edward Elgar: Northampton, UK.

Heidt, V. and Neef, M., 2008. Benefits of urban green space for improving urban climate, in Carreiro, in M.M., Song, Y.C. andWu, J. (Eds), Ecology, Planning, and Management of Urban Forests: International Perspectives (pp. 84-96), Springer, New York.

Iamtrakul, P., Teknomo, K., and Hokao, K., 2005. Public Park Valuation Using Travel Cost Method, Proceedings of the Eastern Asia Society for Transportation Studies, 5:1249-1264.

Jackson, L.E., 2003. The relationship of urban design to human health and condition. Landscape Urban Planning, 64:191-200.

Jayaratne, C.T. and Gunawardena, U.A.D.P., 2004. Estimation of local recreational value of Hakgala Botanical Garden. Proceedings of Ninth International Forestry and Environment Symposium of the Department of Forestry and Environmental Science, University of Sri Jayewardenepura, Sri Lanka, 27-28 February.

Jorgensen, A., Hitchmough, J., and Calvert, T., 2002. Woodland spaces and edges: Their impact on perception of safety and preference. Landscape Urban Planning, 60:135-150.

Jim, C.Y. and Chen, W. Y., 2006. Recreation-amenity use and contingent valuation of urban green spaces in Guangzhou, China. Landscape and Urban Planning, 75:81-96.

Kaliampakos, D., andDamigos, D., 1999. Using Environmental Economics to Evaluate Quarry Rehabilitation Alternatives. 60 Conference of Environmental Science and Technology. Samos.

Lakpura, 2020. Retrieved 15, June from https://lakpura.com/viharamahadevi-park.

Limaei, S. M., Ghesmati, H., Rashidi, R. and Yamini, N., 2014. Economic evaluation of natural forest park using the travel cost method (case study; Masouleh forest park, north of Iran), Journal of Forest Science, 60:254-261.

Luttik J., 2000. The value of trees, water and open space as reflected by house prices in the Netherlands, Landscape and Urban Planning, 48:161-167.

Maduwanthika M.C.A. and Gunawardena U.A.D.P., 2017. Estimation of local recreational value of Seethawaka wet zone botanical garden, $22^{\text {nd }}$ International Forestry and Environment Symposium, Organized by: Deptment of Forestry and Environmental Science, University of Sri Jayewardenepura, Tangerine Beach Hotel, Kalutara, 10-11 November.

Marawila T.D. and M. Thibbotuwawa, 2010. To Develop or to Conserve? The Case of the Diyawanna Oya Wetlands in Sri Lanka, (SANDEE Working Paper No. 52-10, Kathmandu Nepal.

Mathieu, L.F., Langford,I.H. and Kenyon, W., 2003. Valuing Marine Parks in a Developing Country: A Case Study of the Seychelles, Environment and Development Economics, 8:373-390.

Matthew, N.K, Shuib, A., Ramachandran, S. and Herman, S., 2013. Demand Model of International Visitors to the Kilim Karst Geoforest Park, Langkawi: Application of Item Model, Journal of Applied Economics and Business, 1:51-66.

Navrud, S., and Mungatana, E.D., 1994. Environmental valuation in developing countries: The recreational value of wildlife viewing, Ecological Economics, 135-151.

Pearce, D., Markandya, A., Barbier, E.B., 1989. Blueprint for a green economy. Earthscan Publications Limited, London.

Perman, R., Ma, Y., McGilvray, J. and Common, M., 2003. Natural resource and environmental economics. Pearson Education.

Rakhshandehroo, M., Yusof, M.J., M., Arabi, R., Parva, M., and Nochian, A., 2017. The environmental benefits of urban open green spaces. Alam Cipta, 10:10-15. 
Rathnayake, R.M.W. and Gunawardena, U.A.D.P., 2002. Estimation of recreational value of the Wasgamuwa national park. Paper presented at the International Conference on relating the environment to regional development organised by USJ/ SIDA/ SAREC Research Co-operation Project and Ministry of Environment and Natural Resources, Colombo, Sri Lanka, 16-18 September.

Rathnayake, R.M.W. and Gunawardena, U.A.D.P., 2013. Social carrying capacity of Horton Plains national park, Sri Lanka. Sri Lanka Journal of Social Sciences, Vol 35.

Rathnayake, R.M.W. and Gunawardena, U.A.D.P., 2011. Estimation of recreational value of Horton Plains national park in Sri Lanka: A decision making strategy for natural resource management. Journal of Tropical Forestry and Environment, 1:71-86.

Smith, R.M., Gaston, K.J., Warren, P.H., and Thompson, K., 2005. Urban domes- tic gardens (V): relationships between land cover composition, housing and landscape. Landscape Ecology, 20:235-253.

Takano, T., Nakamura, K. and Watanabe, M., 2002. Urban residential environments and senior citizens longevity in megacity area: the importance of walkable green spaces, Journal Epidemiol Community Health, 56:913-18.

Twerefou, D.K., and Ababio, D.K.A., 2012. An economic valuation of the Kakum national park: An individual travel cost approach, African Journal of Environmental Science and Technology, 6:199-207.

Tzoulas, K., Korpela, K., Venn, S., Yli-Pelkonen, V., Kaz 'mierczak, A., Niemela, J. and James, P., 2007. Promoting ecosystem and human health in urban areas using green infrastructure: A literature review, Landscape and Urban Planning, 81:167-78.

Ulrich, R.S., Simons, R.F., Losito, B.D., Fiorito, E., Miles, M.A. and Zelson, M., 1991. Stress recovery during exposure to natural and urban environments, Journal of Environmental Psychology, 11:201-230.

University of Moratuwa, 2011. Environmental Screening Report for Model Zone Development of Town Hall Square, Uni Consultancy Service, University of Moratuwa.

Weerasekara, L.H.P., 2015. An approach of contingent valuation method of Weras Ganga recreational park, research report of department of estate management and valuation, University of Sri Jayewardenepura.

Wickramarachchi, A.H. and Gunawardena, U.A.D.P., 2012. Estimation of Recreational value of Leopards at Yala National Park Sri Lanka. Proceedings of the Seventeenth International Forestry and Environment Symposium organised by the Department of Forestry and Environmental Science, University of Sri Jayewardenepura.

Wu, J., 2008. Toward a landscape ecology of cities: beyond buildings, trees, and urban forests, In: Carreiro, M.M., Song, Y.C. and Wu, J. (Eds), Ecology, Planning, and Management of Urban Forests: International Perspectives (pp. 10-28), Springer, New York.

Zhou, X., and Rana, M.M.P., 2012. Social benefits of urban green space: A conceptual framework of valuation and accessibility measurements, Management of Environmental Quality: An International Journal, 23:173-189. 